Article

\title{
Virulence of Beauveria bassiana Strains Isolated from Cadavers of Colorado Potato Beetle, Leptinotarsa decemlineata
}

\author{
Rostislav Zemek $^{1, *(\mathbb{C})}$, Jana Konopická ${ }^{1}\left(\mathbb{D}\right.$, Eva Jozová $^{2} \mathbb{C}$ and Oxana Skoková Habuštová ${ }^{1}$ (D) \\ 1 Biology Centre CAS, Institute of Entomology, 37005 České Budějovice, Czech Republic; \\ jkonopicka@seznam.cz (J.K.); habustova@entu.cas.cz (O.S.H.) \\ 2 Department of Genetics and Agricultural Biotechnology, Faculty of Agriculture, University of South Bohemia, \\ 37005 České Budějovice, Czech Republic; evondras@gmail.com \\ * Correspondence: rosta@entu.cas.cz
}

Citation: Zemek, R.; Konopická, J.; Jozová, E.; Skoková Habuštová, O. Virulence of Beauveria bassiana Strains Isolated from Cadavers of Colorado Potato Beetle, Leptinotarsa decemlineata. Insects 2021, 12, 1077. https://doi.org/10.3390/insects 12121077

Academic Editor: Jørgen Eilenberg

Received: 19 October 2021

Accepted: 29 November 2021

Published: 30 November 2021

Publisher's Note: MDPI stays neutral with regard to jurisdictional claims in published maps and institutional affiliations.

Copyright: (c) 2021 by the authors. Licensee MDPI, Basel, Switzerland. This article is an open access article distributed under the terms and conditions of the Creative Commons Attribution (CC BY) license (https:// creativecommons.org/licenses/by/ $4.0 /)$.
Simple Summary: The Colorado potato beetle is a serious insect pest, attacking mainly potato. This pest causes severe yield loss all over the world and it is difficult to control by chemical pesticides because it quickly develops resistance to them. In our study we investigated the potential of the fungus Beauveria bassiana, a natural pathogen of insects, to kill adults of the Colorado potato beetle. The novelty of this study is that strains of the fungus were isolated from naturally infected adults of the pest which were collected in potato fields in the Czech Republic. A suspension of B. bassiana spores was applied to test beetles and their survival was observed under constant conditions. Obtained results revealed that some strains of the fungus were able to kill almost all treated beetles in 21 days and can be therefore recommended for the development of a new biopesticide. The results of this study can thus be applied in effective biological control of the most serious pest of potato.

Abstract: The Colorado potato beetle, Leptinotarsa decemlineata (Say), is a serious, widely distributed pest of potato and other crops. This pest is able to defoliate the host plant and cause severe yield loss. Moreover, the pest quickly becomes resistant to many chemical pesticides. Therefore, the development of novel biopesticides targeting this pest is urgently needed. The purpose of this study was to obtain new strains of the entomopathogenic fungus Beauveria bassiana and assess their efficacy against L. decemlineata adults under laboratory conditions. Twelve strains were isolated from cadavers of Colorado potato beetles collected in potato fields in the Czech Republic. Test beetles were treated by suspensions of conidia at the concentration of $1 \times 10^{7}$ spores per milliliter and their survival was recorded daily for three weeks. The results of the bioassays revealed that all new native strains were pathogenic to L. decemlineata adults and caused mortality up to $100 \%$ at the end of the trial period with an $\mathrm{LT}_{50}$ of about 7 days. These strains were more virulent than a reference strain GHA and some of them can be recommended for the development of a new mycoinsecticide against L. decemlineata. Our findings also highlight the importance of searching for perspective strains of entomopathogenic fungi among naturally infected hosts.

Keywords: potato; insect pest; entomopathogenic fungi; biological control; efficacy; mycoinsecticides

\section{Introduction}

The Colorado potato beetle (CPB), Leptinotarsa decemlineata (Say) (Coleoptera: Chrysomelidae), is a serious pest of potatoes (Solanum tuberosum L.) in the USA and Europe as well as in Asia [1-3]. The biology and history of its spread have been reviewed in detail elsewhere $[4,5]$. Adults and larvae feed on leaves and can develop two complete generations in warm regions. Without control measures, the beetle can cause severe reductions in tuber yield or quality (tuber size) [5]. Chemical pesticides which have been used frequently for the last few decades to manage this pest are, however, often hazardous for human health as well as the ecosystem. In addition, CPB has evolved resistance to many registered 
pesticides [6-11] and $\mathrm{CPB}$ thus becomes one of the most difficult insect pests to control. Resistance of CPB to chemical pesticides, concern about their harmful effects on the environment, and increasing public demand for reduction of pesticide residues in food call for alternative, safer, yet effective control agents [12-14].

In addition to arthropod natural enemies of $\mathrm{CPB}$, such as carabid beetles [15], lacewings larvae [16] and lady beetles [17], and besides entomopathogenic nematodes [18,19] or Bacillus thuringiensis [20], biological control using mycoinsecticides can be a good, environmentally friendly alternative to broad-spectrum chemical insecticides [21]. Many biopesticides based on entomopathogenic fungi (EPF) such as Beauveria bassiana (Bals.-Criv.) Vuill., Isaria fumosorosea Wize (Hypocreales: Cordycipitaceae), or Metarhizium anisopliae (Metsch.) Sorokin (Hypocreales: Clavicipitaceae) have been developed worldwide since the 1960s [22]. Their advantages are that they can be relatively easily produced, are able to penetrate the host cuticle so they do not need to be ingested [23], and there is no risk of resistance development in target pests and none or few side effects on non-target organisms. Moreover, synergistic combinations of microbial control agents with other technologies are expected to occur in the future [24].

The efficacy of several EPF species against CPB has been investigated in many studies. For example, in various experiments, including field trials with Isaria farinosa (Holmsk.) Fr. alone and in combination with other fungi, high efficacy of fungus treatment was reported in Poland [25,26], the Czech Republic [27], and in Austria [28]. Another species of entomopathogenic fungus successfully tested against CPB was I. fumosorosea. Strain CCM 8367 of this species isolated from Cameraria ohridella, Deschka and Dimić (Lepidoptera: Gracillariidae) [29-31] caused high mortality against CPB larvae under laboratory conditions [19]. Field trials of another study revealed that potato plots treated with I. fumosorosea or B. bassiana had significantly higher tuber yield compared to an untreated control but still lower than the yield obtained from the plots protected with chemical pesticides [32]. Similar results were obtained in small field plot experiments in the USA [33]. A study on the effect of $B$. bassiana on foliage consumption by CPB larvae revealed that the treatment reduced leaf consumption by up to $76.2 \%$, and increasing the fungus dose reduced the larval feeding period [34]. Wraight and Ramos reported significant reductions of CPB populations after B. bassiana foliar treatments $[35,36]$. The highest sensitivity of CBP to B. bassiana (strain NDBJJ-BFG) was reported in the youngest larval instars using when $\mathrm{LC}_{50}$ was only $10^{5}-10^{6}$ while in adults $\mathrm{LC}_{50}$ values were $10^{7}-10^{8}$ [37]. A recent laboratory study of 14 Turkish isolates of $B$. bassiana showed high variability in mortality among the strains and developmental stages of CPB. Some isolates caused the highest mortality between 96.7 and $100 \%$ in the 1st and 2nd instar larvae [38] when they were sprayed with a suspension of $1 \times 10^{7}$ conidia per $\mathrm{mL}$.

The present study was aimed to assess the virulence of new strains of B. bassiana isolated against CPB adults. The novelty of the study is that strains were isolated from naturally infected $L$. decemlineata collected in the Czech Republic. The obtained results are intended to contribute to the development of safe and efficient biocontrol of the most serious pest of potato.

\section{Materials and Methods}

\subsection{Beauveria Bassiana Strains}

Twelve strains were isolated from naturally B. bassiana-infected adults of $L$. decemlineata found among hundreds of beetles collected in several commercial and experimental potato fields in South and West Bohemia, the Czech Republic, during the spring season in 2019. The beetles from different populations were kept isolated under greenhouse conditions for 1-2 weeks on potted potato plants (cv. Magda) grown from in vitro cultures in sterilized soil substrate. Dead individuals were placed on sterile wet filter paper in Petri dishes to stimulate the growth of fungi. EPF strains were isolated from $\mathrm{CPB}$ cadavers showing mycosis symptoms typical for $B$. bassiana infection. The strains were purified using a selective medium based on Potato Dextrose Agar (PDA) (Sigma-Aldrich, Darmstadt, Germany) 
with a fungicide dodine $(0.05 \mathrm{~g} / \mathrm{L})$ and antibiotics cycloheximide $(0.25 \mathrm{~g} / \mathrm{L})$ and chloramphenicol (0.5 g/L) (Sigma-Aldrich, Darmstadt, Germany) [39].

Species identification of the strains was verified on the basis of macroscopic, microscopic, and genetic characteristics. DNA for genetic analysis was extracted from fresh mycelium grown at $25 \pm 1{ }^{\circ} \mathrm{C}$ for 7 days on Petri dishes with PDA medium. Each mycelium was collected in a sterile $1.5 \mathrm{~mL}$ microtube. The extraction method used was based on CTAB-PVP [40] with modification for fungi. Genomic DNA was amplified by PCR with universal primers NL1 5'-GCATATCAATAAGCGGAGGAAAAG-3' (forward) and NL4 5'GGTCCGTGTTTCAAGACGG-3' (reverse) [41,42]. PCR reactions were carried out in a volume of $25 \mu \mathrm{L}$ contained in $1 \times$ reaction buffer $(75 \mathrm{mM}$ Tris- $\mathrm{HCl}, \mathrm{pH}=8.8,20 \mathrm{mM}$ $\left(\mathrm{NH}_{4}\right)_{2} \mathrm{SO}_{4}, 0.01 \%$ Tween ${ }^{\circledR} 20,2.5 \mathrm{mM} \mathrm{MgCl} 2,200 \mu \mathrm{M}$ dNTPs) (Sigma-Aldrich, Darmstadt, Germany), 1.25 U Taq Purple DNA polymerase (PPP Master Mix, Top-Bio Ltd., Vestec, Czech Republic), 10 pmol of both forward and reverse primer, and 50 ng template DNA. Microtubes were placed in a thermal cycler TProfessional Basic Gradient (Biometra GmbH, Göttingen, Germany) with the following program: 1 cycle of $94^{\circ} \mathrm{C}$ for $5 \mathrm{~min}, 25$ cycles of $94{ }^{\circ} \mathrm{C}$ for $1 \mathrm{~min}, 50^{\circ} \mathrm{C}$ for $1 \mathrm{~min}, 72{ }^{\circ} \mathrm{C}$ for $1 \mathrm{~min}$ and $15 \mathrm{~s}$, and final elongation at $72{ }^{\circ} \mathrm{C}$ for $5 \mathrm{~min}$. The part of amplified PCR products was visualized on $2 \%$ agarose gel. The PCR products were sequenced by SEQme Ltd. (Dobřišs, Czech Republic). The sequences obtained were edited, compiled, and aligned using Geneious (Auckland, New Zealand) software. Sequence similarity searches were performed using NCBI GenBank BLASTn.

Cultures are deposited at the Biology Centre of the Czech Academy of Sciences, Institute of Entomology, České Budějovice. GenBank accession numbers for all 12 strains are listed in Table 1. In addition, B. bassiana strain GHA was re-isolated from commercial mycopesticide BotaniGard ${ }^{\circledR}$ WP (Certis USA, L.L.C., Butte, MT, USA) and used as a reference strain in efficacy bioassays.

Table 1. Strains of Beauveria bassiana isolated within this study and used in bioassays.

\begin{tabular}{cccc}
\hline Strain & Sampling Site & GPS Coordinates & Genbank Accession Number \\
\hline Bb1 & České Budějovice & $48.97417^{\circ} \mathrm{N}, 14.44867^{\circ} \mathrm{E}$ & $\mathrm{MN560148.1}$ \\
$\mathrm{Bb} 2$ & České Budějovice & $48.97601^{\circ} \mathrm{N}, 14.44720^{\circ} \mathrm{E}$ & $\mathrm{MN749309}$ \\
$\mathrm{Bb} 3$ & České Budějovice & $48.97417^{\circ} \mathrm{N}, 14.44867^{\circ} \mathrm{E}$ & $\mathrm{MN749310}$ \\
$\mathrm{Bb} 4$ & Malonty $^{1}$ & $48.69105^{\circ} \mathrm{N}, 14.58950^{\circ} \mathrm{E}$ & $\mathrm{MN749311}$ \\
$\mathrm{Bb} 5$ & Malonty $^{1}$ & $48.69105^{\circ} \mathrm{N}, 14.58950^{\circ} \mathrm{E}$ & $\mathrm{MN749312}$ \\
$\mathrm{Bb} 6$ & Malonty & $48.69105^{\circ} \mathrm{N}, 14.58950^{\circ} \mathrm{E}$ & $\mathrm{MN749313}$ \\
$\mathrm{Bb} 7$ & Bělčice & $49.50702^{\circ} \mathrm{N}, 13.89545^{\circ} \mathrm{E}$ & $\mathrm{MN} 749314$ \\
$\mathrm{Bb} 8$ & Bělčice & $49.50702^{\circ} \mathrm{N}, 13.89545^{\circ} \mathrm{E}$ & $\mathrm{MN749316}$ \\
$\mathrm{Bb} 9$ & Oblajovice & $49.44965^{\circ} \mathrm{N}, 14.88024^{\circ} \mathrm{E}$ & $\mathrm{MN749317}$ \\
$\mathrm{Bb} 10$ & Bojanovice & $49.29724^{\circ} \mathrm{N}, 13.62259^{\circ} \mathrm{E}$ & $\mathrm{MN749318}$ \\
$\mathrm{Bb} 11$ & Bojanovice & $49.29724^{\circ} \mathrm{N}, 13.62259^{\circ} \mathrm{E}$ & $\mathrm{MN749319}$ \\
$\mathrm{Bb} 12$ & Bojanovice & $49.29724^{\circ} \mathrm{N}, 13.62259^{\circ} \mathrm{E}$ & \\
\hline
\end{tabular}

${ }^{1}$ Organic farm.

\subsection{Preparation of Fungal Suspension}

Beauveria bassiana strains were grown on Petri dishes (ø $90 \mathrm{~mm}$ ) containing PDA (Sigma-Aldrich, Munich, Germany, $39 \mathrm{~g} / \mathrm{L}$ ). The plates were incubated at $25^{\circ} \mathrm{C}$ in the dark for 10-14 days. The aerial conidia were harvested by scraping them into a sterile solution of $0.05 \%(v / v)$ Tween $80^{\circledR}$ (Sigma-Aldrich, Munich, Germany). The conidial suspension was filtered through sterile gauze to separate the mycelium and clusters of conidia. In the uniform suspension, the spores were counted with a Neubauer improved counting chamber (Sigma-Aldrich, Munich, Germany) and, subsequently, the suspension was adjusted to a concentration of $1 \times 10^{7}$ conidia per mL. The suspension was left for approximately $12 \mathrm{~h}$ at temperature $23 \pm 1{ }^{\circ} \mathrm{C}$ to accelerate and synchronize germination of conidia [43,44] before its application. The viability of spores was verified using a standard germination test [45]. Ten drops from suspension were applied using a $1 \mu \mathrm{L}$ inoculation loop on the surface of $2 \%$ water agar, which was poured in a thin layer onto the surface of a sterile slide. After the 
drops had dried, the slides were moved into a wet chamber and incubated at $25 \pm 1{ }^{\circ} \mathrm{C}$ for $24 \mathrm{~h}$. The percentage of germinating spores was determined using an Olympus $\mathrm{CH} 20$ light microscope (Olympus Optical Co., Ltd., Tokyo, Japan); bright field, $400 \times$ magnification. The spore germination of all strains was $>98 \%$.

\subsection{Bioassays}

The efficacy of individual B. bassiana strains was tested on CPB adults collected in an organic potato field in Malonty, South Bohemia, Czech Republic. The beetles were individually immersed in the suspension of conidiospores of the fungus $\left(1 \times 10^{7}\right.$ spores per $\mathrm{mL}$ ) for $30 \mathrm{~s}$ (dip-test). All specimens in a control group were immersed in a sterile solution of $0.05 \%$ Tween ${ }^{\circledR} 80$ only. The beetles were then placed into polystyrene Petri dishes (vented, inner diameter $90 \mathrm{~mm}$, height $15 \mathrm{~mm}$, Gosselin ${ }^{\mathrm{TM}}$, Borre, France) lined with moist filter paper KA 0 (Papírna Perštejn Ltd., Pernštejn, Czech Republic) and kept under constant conditions ( $25 \pm 1{ }^{\circ} \mathrm{C}$ and 16L:8D photoperiod). Fresh leaves from potted potato plants (cv. Magda) grown under greenhouse conditions were added daily to provide food for beetles. The filter paper was also daily moistened with distilled water to maintain optimal humidity inside the Petri dishes and replaced with a new one once a week. The insects were monitored daily for 21 days to record insect mortality and development of mycosis on cadavers. Only mycosis verified by microscopic examination of sporulating fungus as $B$. bassiana was considered. The bioassays were repeated twice; each replication tested 30 insect individuals.

\subsection{Statistical Analysis}

Cumulative mortality data were subjected to survival analysis. The Kaplan-Meier product limit estimate calculated in the LIFETEST procedure of SAS/STAT ${ }^{\circledR}$ (SAS Institute, Gary, NC, USA) module [46] was used to determine both the mean and the median time to death ( $\mathrm{LT}_{50}$, the number of days until $50 \%$ of insects were dead) for each strain. Log-rank test statistics (PROC LIFETEST) was used to test the global hypothesis that mortality (time to death) differed between strains and Šidák adjustment was used for multiple comparisons. $\mathrm{CPB}$ mortality and mycosis of cadavers at the end of the experiment were expressed as mean percentage \pm standard error of the mean. A generalized linear model with a binomial distribution and logit link was used to analyse data. Treatment and replication were set as fixed effects. The analysis was performed using the GLM procedure (PROC GENMOD) of SAS/STAT ${ }^{\circledR}$ module [46]. Means were separated by the least-square means (LSMEANS) statement of SAS with Tukey-Kramer adjustment for multiple comparisons. The analyses were performed in SAS ${ }^{\circledR}$ Studio for Linux (SAS Institute, Gary, NC, USA) [47]. $p$ values $<0.05$ were considered statistically significant.

\section{Results}

The results of bioassays showed that $B$. bassiana-treated CPB beetles survived much less compared to beetles in control (Figure 1).

Survival analysis revealed a statistically highly significant effect of strain (log-rank test, $\chi^{2}=47.449, p<0.0001$ ) and pairwise comparisons found differences between GHA strain and other strains (Table 2).

As shown in Figure 1, the survival curve of GHA-treated beetles shows an almost linear decline while in other strains most beetles died during a period between 5 and 10 days after treatment, and survival curves had thus a sigmoid shape. The shortest median survival time $\left(\mathrm{LT}_{50}=6.5\right.$ days $)$ was estimated in the $\mathrm{Bb} 2$ strain, the longest $\left(\mathrm{LT}_{50}=12.0\right.$ days $)$ in the GHA strain (Table 2).

Cumulative mortality of $L$. decemlineata adults on the 21st day after treatment reached $26.7 \%$ in the control, while many B. bassiana strains were able to kill almost all treated insects (Figure 2a). 


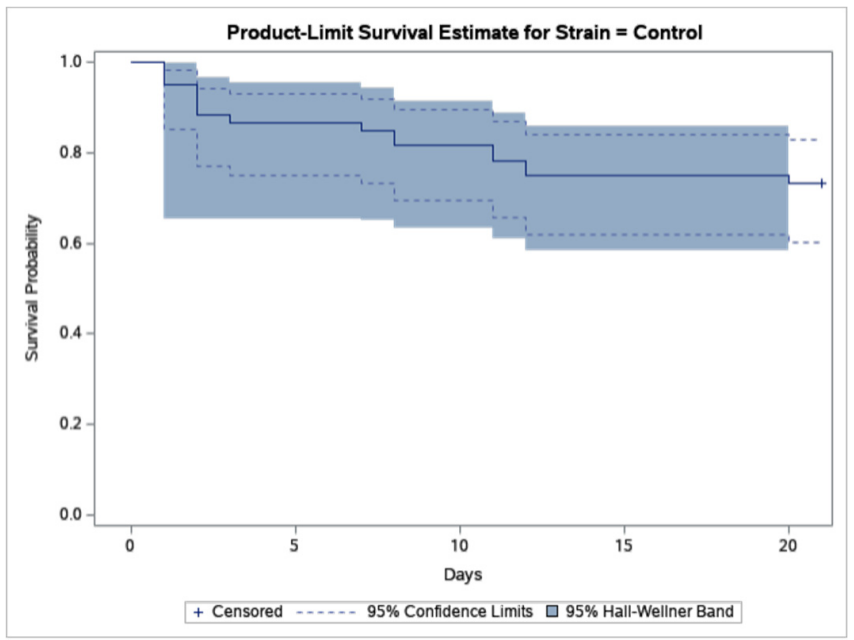

(a)

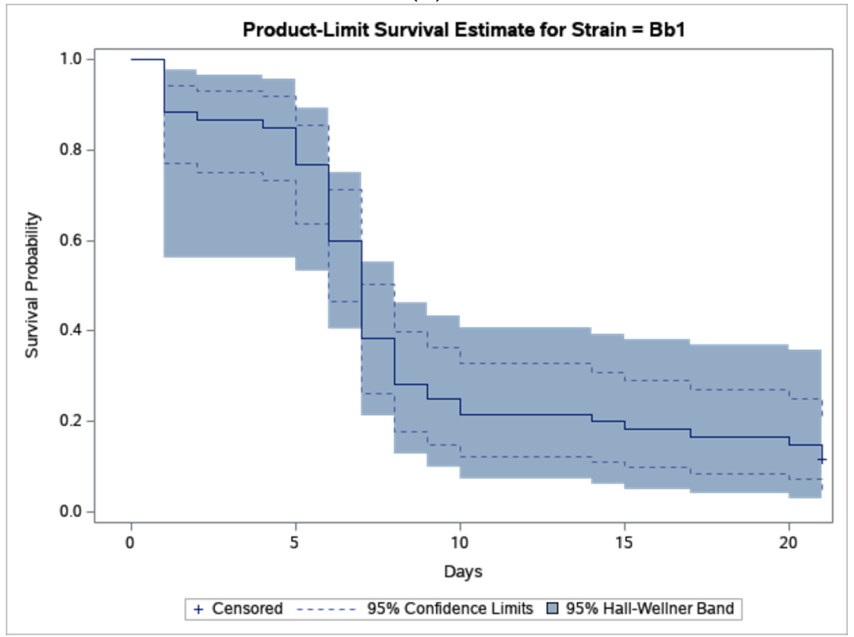

(c)

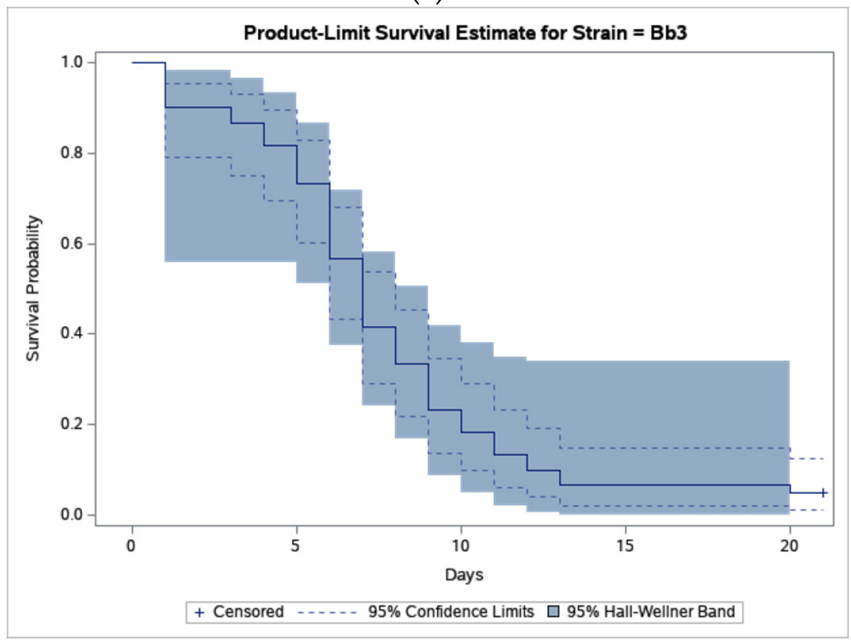

(e)

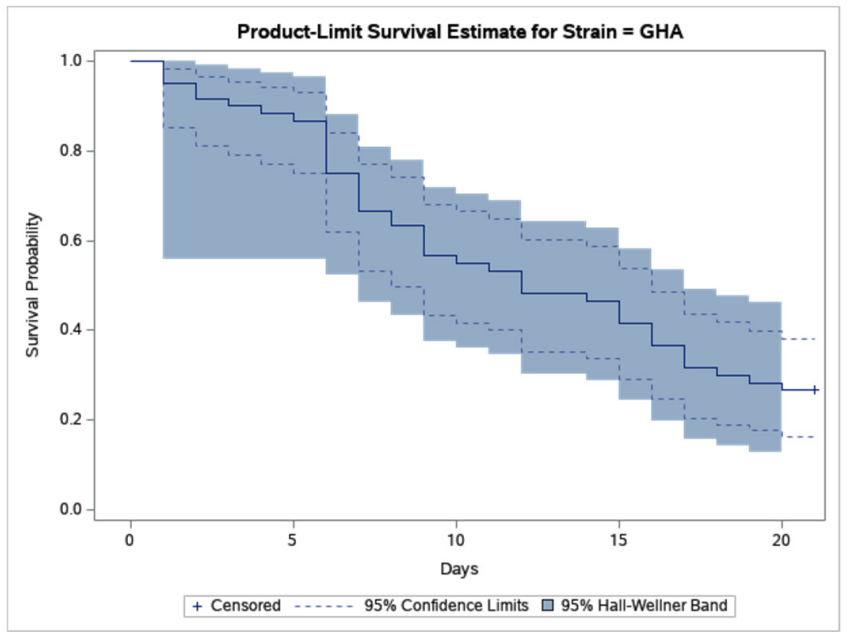

(b)

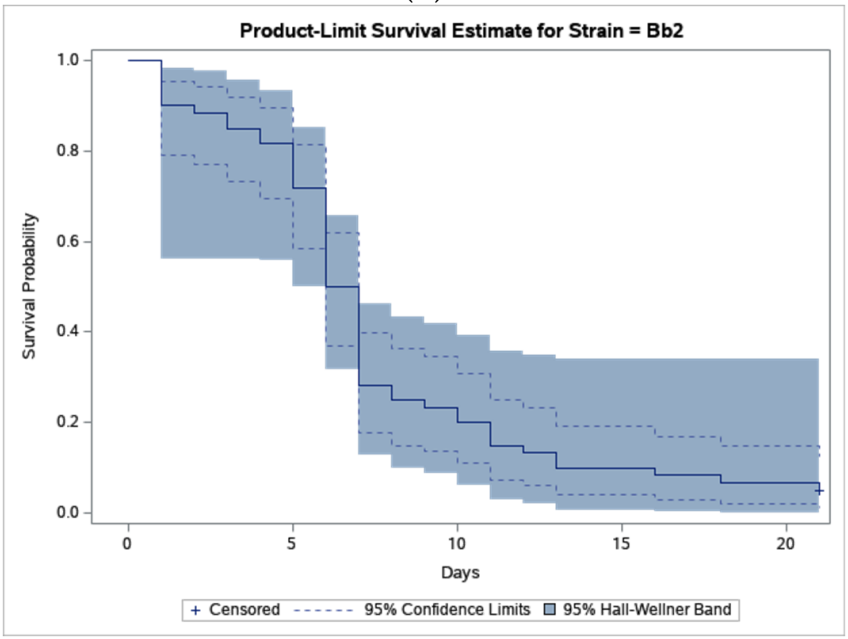

(d)

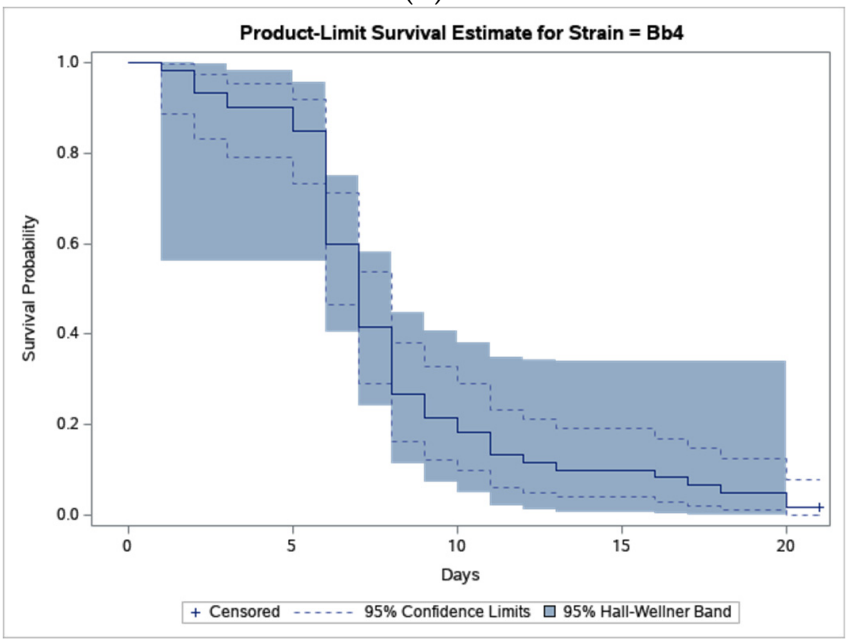

(f)

Figure 1. Cont. 


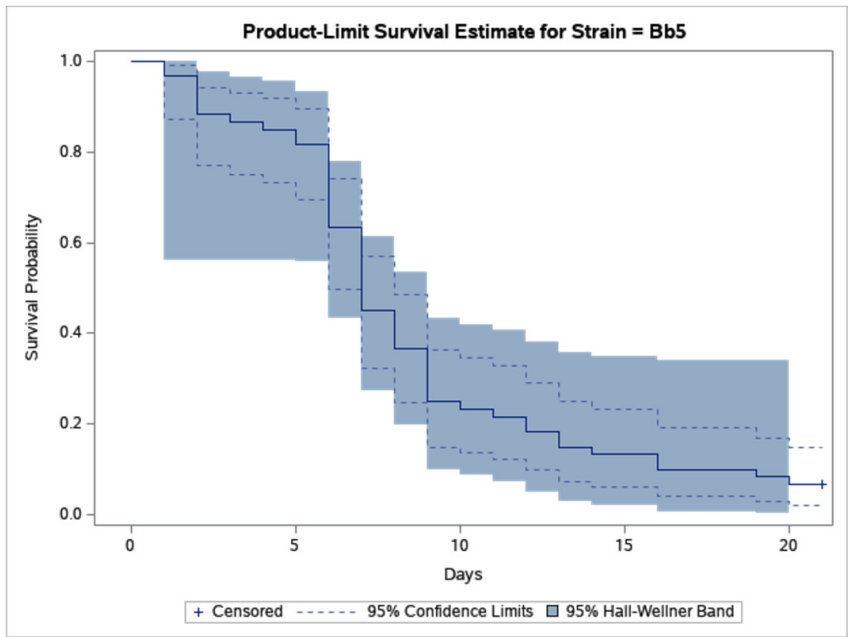

(g)

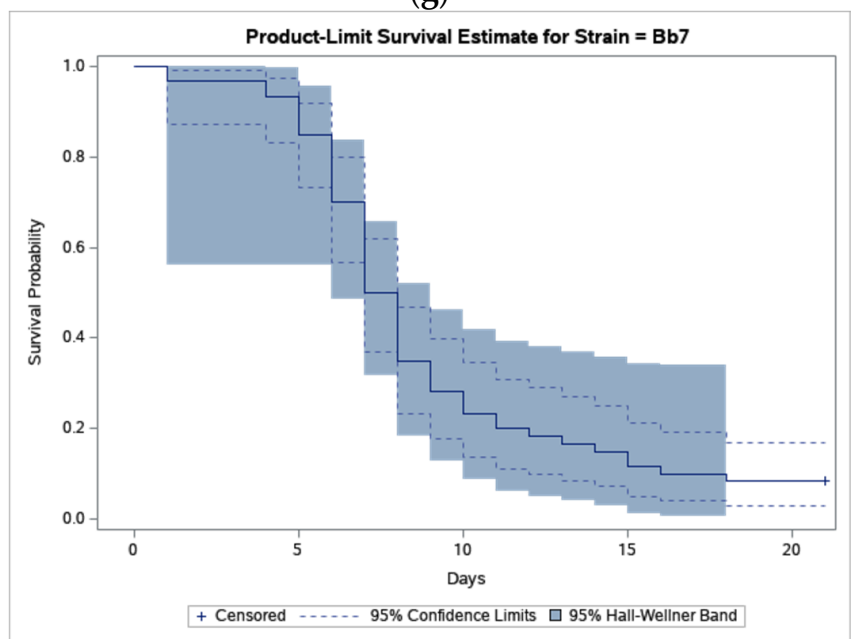

(i)

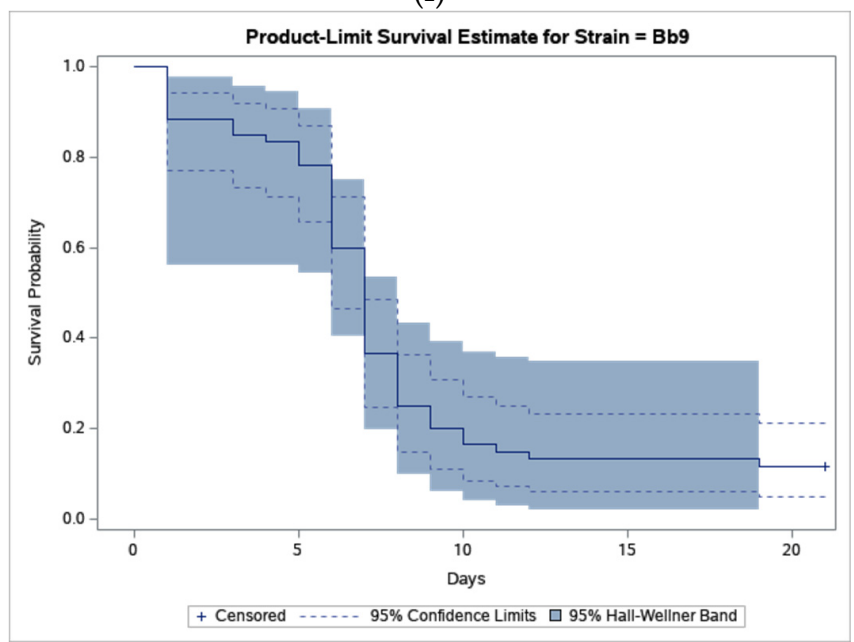

(k)

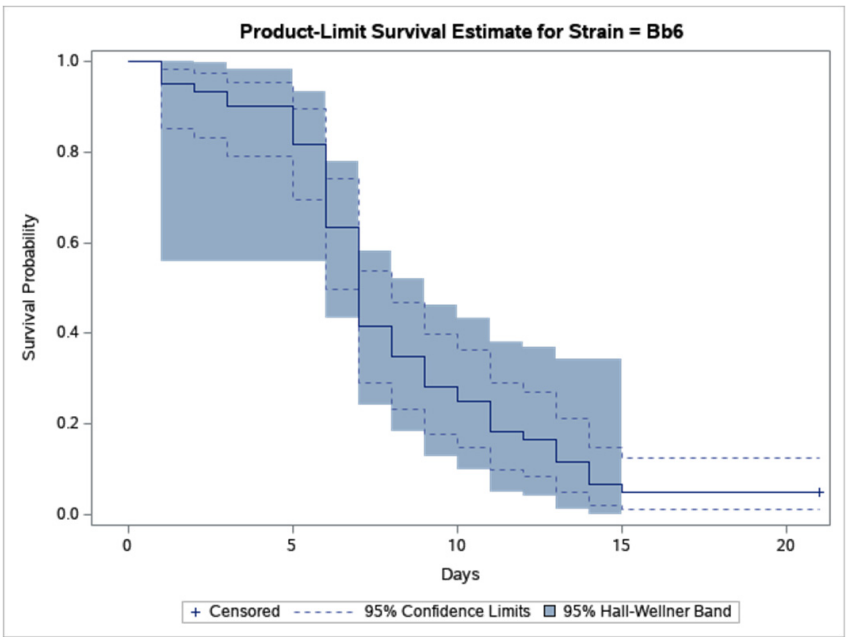

(h)

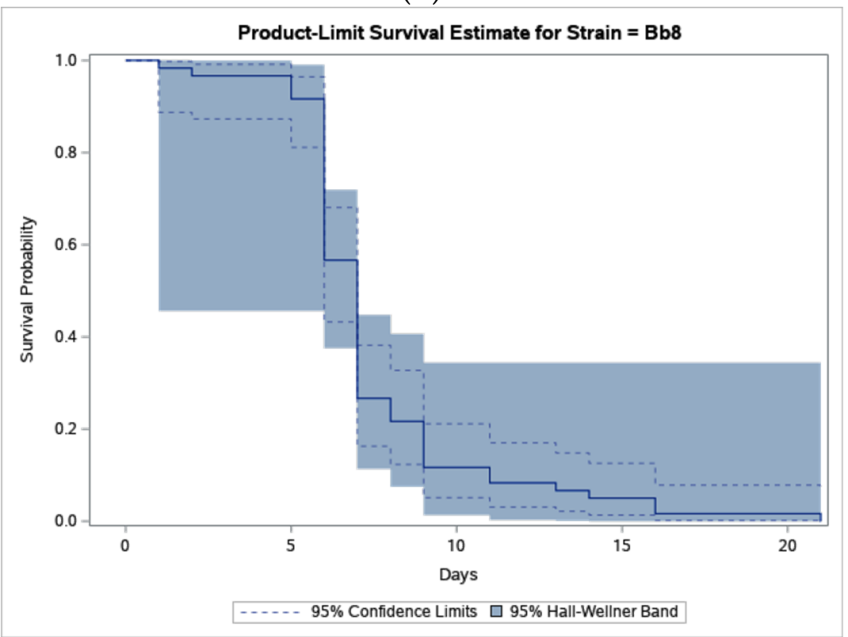

(j)

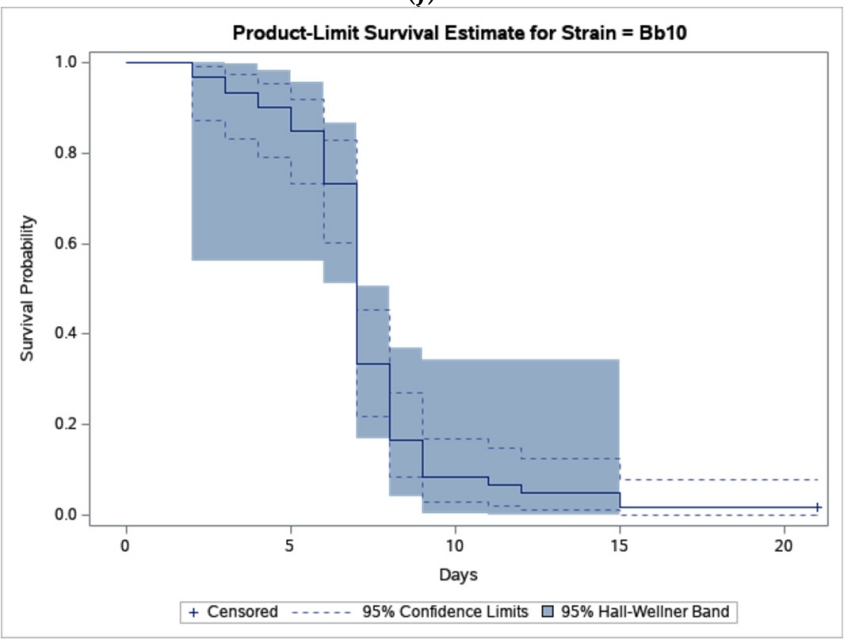

(1)

Figure 1. Cont. 


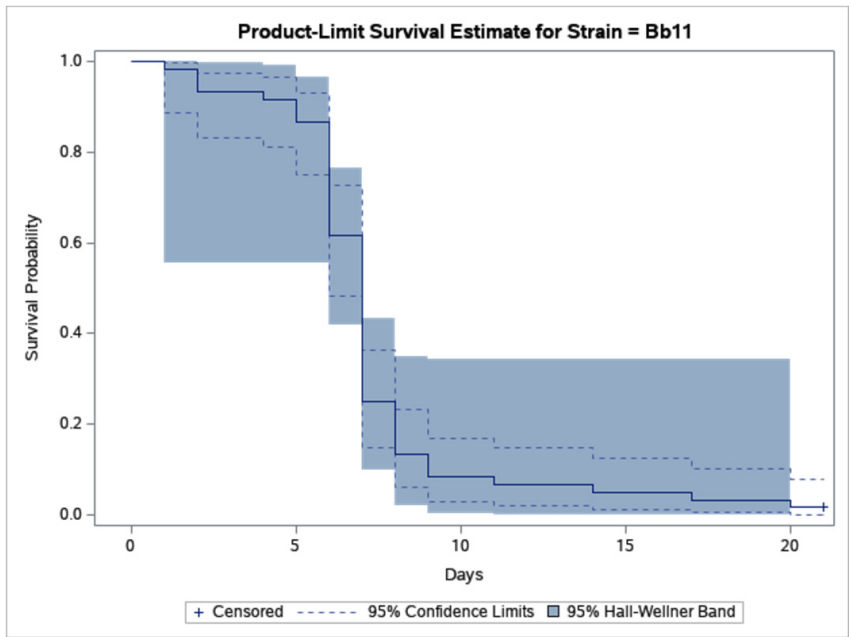

$(\mathbf{m})$

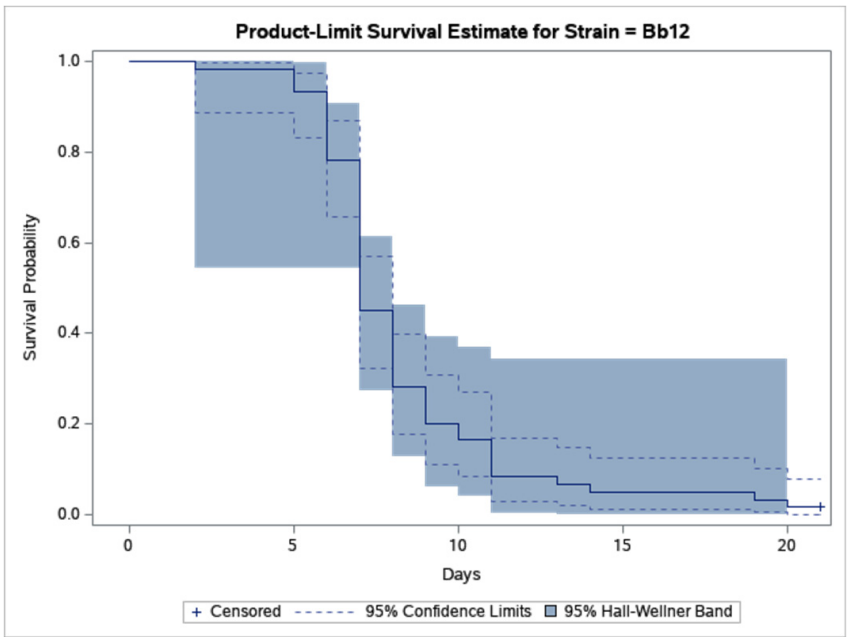

$(\mathbf{n})$

Figure 1. Product-limit survival estimates for Leptinotarsa decemlineata adults treated by Beauveria bassiana or distilled water with 95\% confidence limits (dashed lines) and 95\% Hall-Wellner bands. (a) Control; (b) Strain GHA; (c) Strain Bb1; (d) Strain Bb2; (e) Strain Bb3; (f) Strain Bb4; (g) Strain Bb5; (h) Strain Bb6; (i) Strain Bb7; (j) Strain Bb8; (k) Strain Bb9; (l) Strain Bb10; (m) Strain Bb11; and (n) Strain Bb12.

Table 2. Corrected mortality, mean survival time $( \pm \mathrm{SE})$, and median lethal time $\left(\mathrm{LT}_{50}\right)$ of Leptinotarsa decemlineata adults treated by suspensions of native strains of Beauveria bassiana.

\begin{tabular}{|c|c|c|c|c|}
\hline Strain & Mortality $^{1}(\%)$ & Survival Time $^{2}$ (Days) & $\mathrm{LT}_{50}(95 \% \mathrm{CI})$ (Days) & Log-Rank Test ${ }^{3}$ \\
\hline $\mathrm{Bb} 1$ & 84.09 & $8.83 \pm 0.81$ & $7.0(6.0-8.0)$ & A \\
\hline $\mathrm{Bb} 2$ & 93.18 & $7.58 \pm 0.64$ & $6.5(6.0-7.0)$ & A \\
\hline Bb3 & 93.18 & $7.65 \pm 0.58$ & $7.0(6.0-8.0)$ & $\mathrm{A}$ \\
\hline $\mathrm{Bb} 4$ & 97.73 & $8.05 \pm 0.55$ & $7.0(6.0-8.0)$ & A \\
\hline Bb5 & 90.91 & $8.52 \pm 0.65$ & $7.0(6.0-8.0)$ & A \\
\hline $\mathrm{Bb} 6$ & 93.18 & $7.97 \pm 0.47$ & $7.0(6.0-8.0)$ & $\mathrm{A}$ \\
\hline $\mathrm{Bb} 7$ & 88.64 & $8.77 \pm 0.55$ & $7.5(7.0-8.0)$ & A \\
\hline $\mathrm{Bb} 8$ & 100.00 & $7.50 \pm 0.41$ & $7.0(6.0-7.0)$ & $\mathrm{A}$ \\
\hline $\mathrm{Bb} 9$ & 84.09 & $7.90 \pm 0.65$ & $7.0(6.0-7.0)$ & A \\
\hline $\mathrm{Bb} 10$ & 97.73 & $7.27 \pm 0.33$ & 7.0 (NA-NA) & $\mathrm{A}$ \\
\hline $\mathrm{Bb} 11$ & 97.73 & $7.25 \pm 0.43$ & $7.0(6.0-7.0)$ & A \\
\hline $\mathrm{Bb} 12$ & 97.73 & $8.28 \pm 0.43$ & $7.0(7.0-8.0)$ & $\mathrm{A}$ \\
\hline GHA & 63.64 & $12.33 \pm 0.85$ & $12.0(8.0-16.0)$ & B \\
\hline
\end{tabular}

${ }^{1}$ Percent of dead individuals at the end of experiment corrected for mortality in control using Abbott equation [48]. ${ }^{2}$ The mean survival time and its standard error were underestimated because the largest observation was censored and the estimation was restricted to the largest event time. ${ }^{3}$ Different letters indicate a statistically significant difference between lines ( $p$ values adjusted for multiple comparisons by Šidák).

Mean cumulative mortality at the end of experiments thus ranged between 73.3 and $100 \%$. The most virulent were particularly the strains Bb4, Bb8, Bb10 and Bb11 causing mean mortality higher than $98 \%$. The reference strain GHA showed the lowest efficacy against $L$. decemlineata when mortality was $73.3 \%$ at the end of the trial. The effect of treatment on virulence against CPB was highly significant $\left(\chi^{2}=169.98, \mathrm{df}=13, p<0.0001\right)$ but pairwise comparison showed differences only between control and B. bassiana strains (Figure 1a). Statistically significant were also differences between replications $\left(\chi^{2}=4.56\right.$, $\mathrm{df}=1, p=0.0327$ ).

The average percentage of mycosed cadavers at the end of experiments in the control group was $31.3 \%$. This indicates that about $8.3 \%$ of adults in the field population used in bioassays were naturally infected by $B$. bassiana. Depending on the strain, mycosis ranged between 66.5 and $98.3 \%$ in GHA and Bb12 strains, respectively (Figure 1b). The effect of both the treatment and replication on mycosed cadavers were statistically highly significant 
$\left(\chi^{2}=70.44, \mathrm{df}=13, p<0.0001\right.$ and $\chi^{2}=54.61, \mathrm{df}=1, p<0.0001$, respectively). Pairwise comparison showed some differences among B. bassiana strains (Figure 1b).

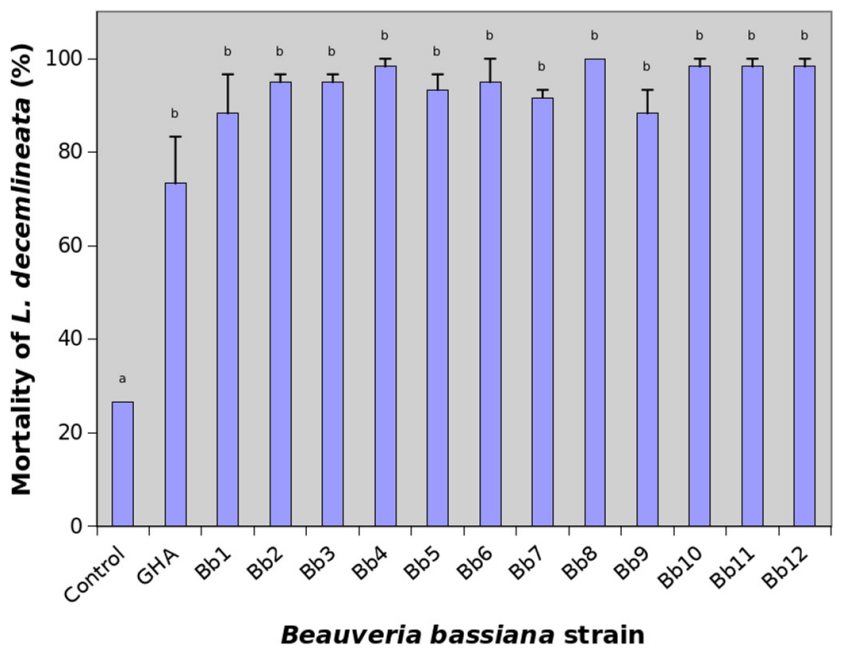

(a)

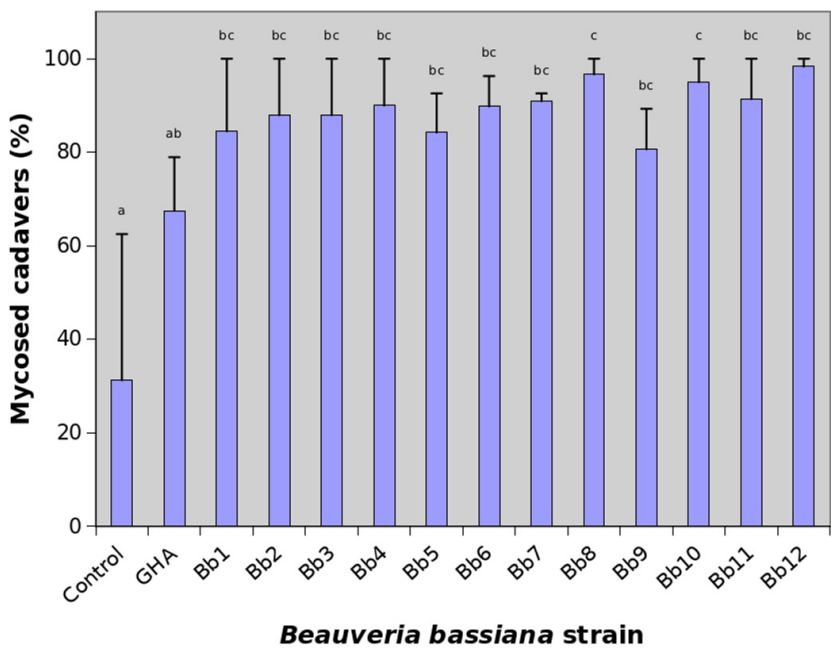

(b)

Figure 2. Percentage of mortality and mycosed cadavers of Leptinotarsa decemlineata adults treated with various strains of Beauveria bassiana 21 days after treatment. See Table 1 for the key to the strains. Data presented are means ( \pm SE), with two replicates of 30 beetles for each strain. A generalized linear model was fitted and pairwise between treatment differences were tested using the least-square means. Different letters indicate significant differences between columns $(p<0.05)$. (a) Mortality; (b) Mycosed cadavers.

\section{Discussion}

Entomopathogenic fungi as biocontrol agents against L. decemlineata have been investigated in many laboratory and field studies. For example, high efficacy against last instar CPB larvae was reported for I. fumosorosea, with the highest mortality reaching $93 \%$ on the 7th day after treatment of insects by suspension of blastospores with a concentration of $5 \times 10^{7}$ spores/mL [19]. Another EPF species, Purpureocillium lilacinum (Thom) Luangsaard, Houbraken, Hywel-Jones and Samson (Hypocreales: Ophiocordycipitaceae), was found to be most effective also on the last larval instar of CPB but mortality was only 33.2\% on the 10th day of treatment with a fungal concentration of $10^{8} \mathrm{CFU} / \mathrm{mL}$ [49]. Results obtained in the present study revealed that B. bassiana-infected adults can be frequently found in field populations of CPB. In the population used in bioassays which originated from an organic farm in Malonty about $8.3 \%$ of beetles were naturally infected. Natural infection of CPB by entomopathogenic fungi was documented by Mietkiewski et al. [50] who found $B$. bassiana to be the dominant fungal pathogen infecting about $21 \%$ of diapausing beetles in Poland. Mortality of CPB adults caused by new native strains isolated within our study reached up to $100 \%$ when beetles were treated by conidia with a concentration of $1 \times 10^{7}$ spores $/ \mathrm{mL}$ with an $\mathrm{LT}_{50}$ of about 7 days. Such efficacy is high for adult CPB beetles because it is known that different developmental stages of CPB have different susceptibility to entomopathogenic fungi, with eggs and adults being the most resistant [51-53]. While in the youngest larval instars the $\mathrm{LC}_{50}$ values for the NDBJJ-BFG strain of B. bassiana were $10^{5}-10^{6}$, in adults the $\mathrm{LC}_{50}$ values ranged between $10^{7}$ and $10^{8}$ spores $/ \mathrm{mL}$ [37]. The highest sensitivity of the 1st and 2nd instar CPB larvae was confirmed by a recent study when some of 14 Turkish B. bassiana isolates applied at a concentration of $1 \times 10^{7}$ conidia per $\mathrm{mL}$ caused mortality between 96.7 and 100\% while they caused lower mortality in eggs and adults [38]. Higher vulnerability of early instars towards B. bassiana is not unique for CPB as it has also been reported for some other insect pests [54,55].

Several field trials demonstrated a good potential of $B$. bassiana to control CPB [32-36,56]. Biocontrol agents are usually applied in the field as a spray, while we used dip test in our laboratory assays. Although spraying insects together with the host plant (potato leaves in 
this case), e.g., using a Potter tower, seems to simulate field application better, a previous study [57] revealed lower efficacy when B. bassiana was applied to potato leaves, and the authors, therefore, recommend developing a formulation targeting the insect cuticle rather than a formulation ensuring spores' long attachment and survival time on the leaf surface. Moreover, several studies have documented that the persistence of EPF spores on plants is limited by many factors such as temperature, rainfall, low humidity, solar radiation, plant chemistry, host plant genotype, fungal strain, etc. [58-69].

Our results further showed little variability in efficacy against CPB adults among native $B$. bassiana strains. This could indicate that the strains are genetically similar and that the sampling site has a relatively low effect when strains are selected naturally via the same host species. Results of a recent study [38] demonstrated significant differences in virulence among $B$. bassiana isolates obtained from the soil by bait method; nevertheless, genetical analysis revealed that all tested isolates had $99 \%$ evolutionary homology with other B. bassiana isolates from the NCBI database.

The present study also showed that the efficacy of new native strains was significantly higher than that of the reference strain GHA which caused intermediate mortality of L. decemlineata adults. GHA strain, the active ingredient of mycopesticide BotaniGard ${ }^{\circledR} \mathrm{WP}$, has been reported to be highly efficient in the control of many arthropod pests [70-74]. This strain was originally isolated from a chrysomelid beetle Diabrotica undecimpunctata Mannerheim (Coleoptera: Chrysomelidae) and host specificity thus might be one of the reasons why it was less effective compared to native strains isolated from naturally infected CPB adults. Similar results were demonstrated by Li et al. [75] who found that the B. bassiana strains isolated from infected mulberry longicorn, Apriona germari (Hope) (Coleoptera: Cerambicidae), caused the highest cumulative mortality rate and the shortest $\mathrm{LT}_{50}$ to the same pest species compared with other strains. The reason might be attributed to the fact that strains were isolated from their original host pest and showed a stronger ability to infect the original host compared with other strains isolated from different insects [76]. This proves that isolation of EPF from the target host might have an advantage of discovering highly virulent strains which can only germinate and expand when it infests its specific host, called host specificity [76-78]. The reason for host specificity is biological long-term coevolution and mutual adaptation, which may have limited the choices of parasites for the host [77]. Genetical aspects of the host specificity were discussed, e.g., by Viaud et al. [79] and Maurer et al. [80]. In the recent study, Zhang et al. [81] sequenced and compared the genome of seventeen B. bassiana isolates obtained from different insect hosts including $L$. decemlineata and concluded that several mutated genes and positively selected genes may underpin the virulence of $B$. bassiana towards hosts during the infection process.

As indicated from the present study, highly virulent strains can be obtained by isolation of EPF from target pests. There are, however, other strain characteristics important for practical applications, such as spore production in mass cultures, low humidity, and UV tolerance or long shelf life of the formulated product, which need to be considered when a particular strain is selected for further steps of mycopesticide development $[82,83]$.

\section{Conclusions}

Our findings demonstrate that most of the native B. bassiana strains isolated from naturally infested $L$. decemlineat $a$ adults showed high virulence against this pest and suggest that this entomopathogenic fungus could be an alternate solution to broad-spectrum chemical insecticides. Results revealed little variability among these strains collected at different sites. Their efficacy was significantly higher than reference strain GHA from BotaniGard $^{\circledR}$, indicating that host species from which the B. bassiana strain is isolated seems to be more important than the geographical origin of the strain. Further research, e.g., genetical analysis, trials under field conditions, development of effective formulations, and study on potential non-target effects, is therefore needed before some of the strains can be recommended for application as a biopesticide. 
Author Contributions: Conceptualization, R.Z. and O.S.H.; methodology, J.K., E.J. and R.Z.; genetical analysis, E.J.; performing experiments, J.K. and R.Z.; data analysis and curation, R.Z.; writingoriginal draft preparation, R.Z.; writing-review and editing, R.Z., J.K., E.J. and O.S.H.; project administration, O.S.H.; funding acquisition, O.S.H. All authors have read and agreed to the published version of the manuscript.

Funding: This research was funded by the National Agency for Agricultural Research (NAZV) Project No. QK1910270. Additional support was obtained from the Czech Academy of Sciences (RVO:60077344). Plant material was provided by the Potato Research Institute Ltd. Havlíčkův Brod, Czech Republic, supported by the grant of the Ministry of Agriculture of the Czech Republic, E-97/01-3160-0200.

Institutional Review Board Statement: Not applicable.

Informed Consent Statement: Not applicable.

Data Availability Statement: The data presented in this study are available on request from the corresponding author.

Acknowledgments: The authors thank Andrea Bohatá for valuable advices concerning entomopathogenic fungi and Barbora Kozelková and Radka Tanzer Fabiánová for their technical assistance.

Conflicts of Interest: The authors declare no conflict of interest. The funders had no role in the design of the study; in the collection, analyses, or interpretation of data; in the writing of the manuscript, or in the decision to publish the results.

\section{References}

1. Jolivet, P. Le doryphore menace l'Asie Leptinotarsa decemlineata Say 1824 (Col. Chrysomelidae). Entomologiste 1991, 47, $29-48$.

2. Weber, D. Colorado Beetle: Pest on the Move. Pestic. Outlook 2003, 14, 256-259. [CrossRef]

3. Hare, J.D. Ecology and Management of the Colorado Potato Beetle. Annu. Rev. Entomol. 1990, 35, 81-100. [CrossRef]

4. Alyokhin, A. Colorado Potato Beetle Management on Potatoes: Current Challenges and Future Prospects. Fruit Veg. Cereal Sci. Biotechnol. 2009, 3, 10-19.

5. Alyokhin, A.; Vincent, C.; Giordanengo, P. (Eds.) Insect Pests of Potato: Global Perspectives on Biology and Management; Elsevier: Amsterdam, The Netherlands; Academic Press: Boston, MA, USA, 2013; ISBN 978-0-12-386895-4.

6. Mota-Sanchez, D.; Hollingworth, R.M.; Grafius, E.J.; Moyer, D.D. Resistance and Cross-Resistance to Neonicotinoid Insecticides and Spinosad in the Colorado Potato Beetle, Leptinotarsa decemlineata (Say) (Coleoptera: Chrysomelidae). Pest Manag. Sci. 2006, 62, 30-37. [CrossRef]

7. Alyokhin, A.; Dively, G.; Patterson, M.; Castaldo, C.; Rogers, D.; Mahoney, M.; Wollam, J. Resistance and Cross-Resistance to Imidacloprid and Thiamethoxam in the Colorado Potato Beetle Leptinotarsa decemlineata. Pest Manag. Sci. 2007, 63, 32-41. [CrossRef]

8. Zichová, T.; Kocourek, F.; Salava, J.; Nad'ova, K.; Stará, J. Detection of Organophosphate and Pyrethroid Resistance Alleles in Czech Leptinotarsa decemlineata (Coleoptera: Chrysomelidae) Populations by Molecular Methods. Pest Manag. Sci. 2010, 66, 853-860. [CrossRef]

9. Szendrei, Z.; Grafius, E.; Byrne, A.; Ziegler, A. Resistance to Neonicotinoid Insecticides in Field Populations of the Colorado Potato Beetle (Coleoptera: Chrysomelidae). Pest Manag. Sci. 2012, 68, 941-946. [CrossRef]

10. Alyokhin, A.; Baker, M.; Mota-Sanchez, D.; Dively, G.; Grafius, E. Colorado Potato Beetle Resistance to Insecticides. Am. J. Potato Res. 2008, 85, 395-413. [CrossRef]

11. Stankovic, S.; Zabel, A.; Kostic, M.; Manojlovic, B.; Rajkovic, S. Colorado Potato Beetle [Leptinotarsa decemlineata (Say)] Resistance to Organophosphates and Carbamates in Serbia. J. Pest Sci. 2004, 77, 11-15. [CrossRef]

12. Alyokhin, A.; Mota-Sanchez, D.; Baker, M.; Snyder, W.E.; Menasha, S.; Whalon, M.; Dively, G.; Moarsi, W.F. The Red Queen in a Potato Field: Integrated Pest Management versus Chemical Dependency in Colorado Potato Beetle Control. Pest Manag. Sci. 2015, 71, 343-356. [CrossRef] [PubMed]

13. Göldel, B.; Lemic, D.; Bažok, R. Alternatives to Synthetic Insecticides in the Control of the Colorado Potato Beetle (Leptinotarsa decemlineata Say) and Their Environmental Benefits. Agriculture 2020, 10, 611. [CrossRef]

14. Kadoić Balaško, M.; Mikac, K.M.; Bažok, R.; Lemic, D. Modern Techniques in Colorado Potato Beetle (Leptinotarsa decemlineata Say) Control and Resistance Management: History Review and Future Perspectives. Insects 2020, 11, 581. [CrossRef]

15. Alvarez, J.M.; Srinivasan, R.; Cervantes, F.A. Occurrence of the Carabid Beetle, Pterostichus melanarius (Illiger), in Potato Ecosystems of Idaho and Its Predatory Potential on the Colorado Potato Beetle and Aphids. Am. J. Potato Res. 2013, 90, 83-92. [CrossRef]

16. Sablon, L.; Haubruge, E.; Verheggen, F.J. Consumption of Immature Stages of Colorado Potato Beetle by Chrysoperla carnea (Neuroptera: Chrysopidae) Larvae in the Laboratory. Am. J. Potato Res. 2013, 90, 51-57. [CrossRef] 
17. Weber, D.C. Biological control of potato insect pests. In Insect Pests of Potato; Academic Press: Oxford, UK, 2013; pp. 399-437, ISBN 978-0-12-386895-4.

18. Wright, R.J.; Agudelo-Silva, F.; Georgis, R. Soil Applications of Steinernematid and Heterorhabditid Nematodes for Control of Colorado Potato Beetles, Leptinotarsa decemlineata (Say). J. Nematol. 1987, 19, 201-206. [PubMed]

19. Hussein, H.M.; Skoková Habuštová, O.; Půža, V.; Zemek, R. Laboratory Evaluation of Isaria fumosorosea CCM 8367 and Steinernema feltiae Ustinov against Immature Stages of the Colorado Potato Beetle. PLoS ONE 2016, 11, e0152399. [CrossRef] [PubMed]

20. Domínguez-Arrizabalaga, M.; Villanueva, M.; Fernandez, A.B.; Caballero, P. A Strain of Bacillus thuringiensis Containing a Novel Cry7Aa2 Gene That Is Toxic to Leptinotarsa decemlineata (Say) (Coleoptera: Chrysomelidae). Insects 2019, 10, 259. [CrossRef]

21. Islam, W.; Adnan, M.; Shabbir, A.; Naveed, H.; Abubakar, Y.S.; Qasim, M.; Tayyab, M.; Noman, A.; Nisar, M.S.; Khan, K.A.; et al. Insect-Fungal-Interactions: A Detailed Review on Entomopathogenic Fungi Pathogenicity to Combat Insect Pests. Microb. Pathog. 2021, 159, 105122. [CrossRef]

22. De Faria, M.R.; Wraight, S.P. Mycoinsecticides and Mycoacaricides: A Comprehensive List with Worldwide Coverage and International Classification of Formulation Types. Biol. Control 2007, 43, 237-256. [CrossRef]

23. Shahid, A.; Rao, Q.; Bakhsh, A.; Husnain, T. Entomopathogenic Fungi as Biological Controllers: New Insights into Their Virulence and Pathogenicity. Arch. Biol. Sci. 2012, 64, 21-42. [CrossRef]

24. Lacey, L.A.; Frutos, R.; Kaya, H.K.; Vail, P. Insect Pathogens as Biological Control Agents: Do They Have a Future? Biol. Control 2001, 21, 230-248. [CrossRef]

25. Bajan, C.; Kmitowa, K. The Effect of Entomogenous Fungi Paecilomyces farinosus Dicks. Brown et Smith and Beauveria bassiana Bals. Vuill. on the Oviposition by Leptinotarsa decemlineata Say Females, and on the Survival of Larvae. Ekol. Pol. 1972, 20, 423-432.

26. Bajan, C.; Fedorko, A.; Kmitowa, K.; Wojciechowska, M. Utilization of Parasitic Microorganisms to Decrease Colorado Beetle Quantity. Bull. L'academie Pol. Sci. Ser. Sci. Biol. 1978, 26, 715-717.

27. Samsinakova, A. Effects of Fungic Preparations on Larvae of Colorado Beetle, Leptinotarsa decemlineata. Acta Entomol. Bohemoslov. 1977, 74, 76-80.

28. Ramisch, I. Paecilomyces farinosus Dicks. Ex Fr. Als Parasit Des Kartoffelkafers Leptinotarsa decemlineata Say. Nova Hedwig. 1976, 271, 199-214.

29. Zemek, R.; Prenerova, E.; Weyda, F. The First Record of Entomopathogenic Fungus Paecilomyces fumosoroseus (Deuteromycota: Hyphomycetes) on the Hibernating Pupae of Cameraria ohridella (Lepidoptera: Gracillariidae). Entomol. Res. 2007, 37, A135-A136.

30. Prenerová, E.; Zemek, R.; Volter, L.; Weyda, F. Strain of Entomopathogenic Fungus Isaria fumosorosea CCM 8367 (CCEFO.011.PFR) and the Method for Controlling Insect and Mite Pests. U.S. Patent No. US 08574566, 5 November 2013.

31. Prenerová, E.; Zemek, R.; Volter, L.; Weyda, F. Strain of Entomopathogenic Fungus Isaria fumosorosea CCM 8367 (CCEFO.011.PFR) and the Method for Controlling Insect and Mite Pests. EPO Patent No. EP2313488, 29 April 2015.

32. Ropek, D.; Kołodziejczyk, M. Efficacy of Selected Insecticides and Natural Preparations against Leptinotarsa decemlineata. Potato Res. 2019, 62, 85-95. [CrossRef]

33. Campbell, R.K.; Anderson, T.E.; Semel, M.; Roberts, D.W. Management of the Colorado Potato Beetle Using the Entomogenous Fungus Beauveria bassiana. Am. Potato J. 1985, 62, 29-37. [CrossRef]

34. Fargues, J.; Delmas, J.C.; Lebrun, R.A. Leaf Consumption by Larvae of the Colorado Potato Beetle (Coleoptera: Chrysomelidae) Infected with the Entomopathogen, Beauveria bassiana. J. Econ. Entomol. 1994, 87, 67-71. [CrossRef]

35. Wraight, S.P.; Ramos, M.E. Application Parameters Affecting Field Efficacy of Beauveria bassiana Foliar Treatments against Colorado Potato Beetle Leptinotarsa decemlineata. Biol. Control 2002, 23, 164-178. [CrossRef]

36. Wraight, S.P.; Ramos, M.E. Delayed Efficacy of Beauveria bassiana Foliar Spray Applications against Colorado Potato Beetle: Impacts of Number and Timing of Applications on Larval and next-Generation Adult Populations. Biol. Control 2015, 83, 51-67. [CrossRef]

37. Yulin, D.; Hui, W.; Zhiyan, M.; Liu, Y.; Xiaodong, D.; Deying, M. Identification and Virulence of a Fungal Entomopathogen Strain NDBJJ-BFG to Colorado Potato Beetle Leptinotarsa decemlineata (Say). J. Plant Prot. 2018, 45, 751-758.

38. Baki, D.; Tosun, H.S.; Erler, F. Efficacy of Indigenous Isolates of Beauveria bassiana (Balsamo) Vuillemin (Deuteromycota: Hyphomycetes) against the Colorado Potato Beetle, Leptinotarsa decemlineata (Say) (Coleoptera: Chrysomelidae). Egypt. J. Biol. Pest Control 2021, 31, 56. [CrossRef]

39. Chase, A.R.; Osborne, L.S.; Ferguson, V.M. Selective Isolation of the Entomopathogenic Fungi Beauveria bassiana and Metarhizium anisopliae from an Artificial Potting Medium. Fla. Entomol. 1986, 69, 285. [CrossRef]

40. Doyle, J. DNA Protocols for Plants. In Molecular Techniques in Taxonomy; Hewitt, G.M., Johnston, A.W.B., Young, J.P.W., Eds.; Springer: Berlin/Heidelberg, Germany, 1991; pp. 283-293. ISBN 978-3-642-83964-1.

41. O'Donnell, K. Ribosomal DNA Internal Transcribed Spacers Are Highly Divergent in the Phytopathogenic Ascomycete Fusarium sambucinum (Gibberella pulicaris). Curr. Genet. 1992, 22, 213-220. [CrossRef]

42. O'Donnell, K. Fusarium and its near relatives. In The Fungal Holomorph: Mitotic, Meiotic and Pleomorphic Speciation in Fungal Systematics; Reynolds, R., Taylor, J.W., Eds.; CAB International: Wallingford, UK, 1993; pp. 225-233.

43. Dillon, R.J.; Charnley, A.K. A Technique for Accelerating and Synchronising Germination of Conidia of the Entomopathogenic Fungus Metarhizium anisopliae. Arch. Microbiol. 1985, 142, 204-206. [CrossRef] 
44. Dillon, R.J.; Charnley, A.K. Initiation of Germination in Conidia of the Entomopathogenic Fungus, Metarhizium anisopliae. Mycol. Res. 1990, 94, 299-304. [CrossRef]

45. Skalický, A.; Bohatá, A.; Šimková, J.; Osborne, L.S.; Landa, Z. Selection of Indigenous Isolates of Entomopathogenic Soil Fungus Metarhizium anisopliae under Laboratory Conditions. Folia Microbiol. 2014, 59, 269-276. [CrossRef]

46. SAS Institute. SAS/STAT 14.3: User's Guide; SAS Institute: Cary, NC, USA, 2017.

47. SAS Institute. SAS Stat Studio 3.8: User's Guide; SAS Institute: Cary, NC, USA, 2018.

48. Abbott, W.S. A Method of Computing the Effectiveness of an Insecticide. J. Econ. Entomol. 1925, 18, 265-267. [CrossRef]

49. Kepenekci, I.; Oksal, E.; Saglam, H.; Atay, T.; Tulek, A.; Evlice, E. Identification of Turkish Isolate of the Entomopathogenic Fungi, Purpureocillium lilacinum (Syn: Paecilomyces lilacinus) and Its Effect on Potato Pests, Phthorimaea operculella (Zeller) (Lepidoptera: Gelechiidae) and Leptinotarsa decemlineata (Say) (Coleoptera: Chrysomelidae). Egypt. J. Biol. Pest Control 2015, 25, 121-127.

50. Miętkiewski, R.; Sapieha, A.; Tkaczuk, C. The Effect of Soil-Borne Entomogenous Fungi on the Mycoses of the Colorado Potato Beetle during Hibernation Period. IOBC-WPRS Bull. 1996, 19, 162-165.

51. Fargues, J.; Delmas, J.-C.; Augé, J.; Lebrun, R.A. Fecundity and Egg Fertility in the Adult Colorado Beetle (Leptinotarsa decemlineata) Surviving Larval Infection by the Fungus Beauveria bassiana. Entomol. Exp. Appl. 1991, 61, 45-51. [CrossRef]

52. Long, D.W.; Drummond, F.A.; Groden, E. Susceptibility of Colorado Potato Beetle (Leptinotarsa decemlineata) Eggs to Beauveria bassiana. J. Invertebr. Pathol. 1998, 71, 182-183. [CrossRef] [PubMed]

53. Fargues, J. Étude des conditions d'infection des larves de doryphore, Leptinotarsa decemlineata say, par Beauveria bassiana (Bals.) Vuill. [Fungi imperfecti]. Entomophaga 1972, 17,319-337. [CrossRef]

54. Hafez, M.; Zaki, F.N.; Moursy, A.; Sabbour, M. Biological Effects of the Entomopathogenic Fungus, Beauveria bassiana on the Potato Tuber Moth Phthorimaea operculella (Seller). Anz. Schädlingskunde Pflanzenschutz Umweltschutz 1997, 70, 158-159. [CrossRef]

55. Tahir, M.; Wakil, W.; Ali, A.; Sahi, S.T. Pathogenicity of Beauveria bassiana and Metarhizium anisopliae Isolates against Larvae of the Polyphagous Pest Helicoverpa armigera. Entomol. Gen. 2019, 38, 225-242. [CrossRef]

56. Hajek, A.E.; Soper, R.S.; Roberts, D.W.; Anderson, T.E.; Biever, K.D.; Ferro, D.N.; LeBrun, R.A.; Storch, R.H. Foliar Applications of Beauveria bassiana (Balsamo) Vuillemin for Control of the Colorado Potato Beetle, Leptinotarsa decemlineata (Say) (Coleoptera: Chrysomelidae): An Overview of Pilot Test Results from the Northern United States. Can. Entomol. 1987, 119, 959-974. [CrossRef]

57. Wraight, S.P.; Ramos, M.E. Effects of Inoculation Method on Efficacy of Wettable Powder and Oil Dispersion Formulations of Beauveria bassiana against Colorado Potato Beetle Larvae under Low-Humidity Conditions. Biocontrol Sci. Technol. 2017, 27, 348-363. [CrossRef]

58. Zimmermann, G. Effect of High Temperatures and Artificial Sunlight on the Viability of Conidia of Metarhizium anisopliae. J. Invertebr. Pathol. 1982, 40, 36-40. [CrossRef]

59. Fargues, J.; Goettel, M.S.; Smits, N.; Ouedraogo, A.; Vidal, C.; Lacey, L.A.; Lomer, C.J.; Rougier, M. Variability in Susceptibility to Simulated Sunlight of Conidia among Isolates of Entomopathogenic Hyphomycetes. Mycopathologia 1996, 135, $171-181$. [CrossRef] [PubMed]

60. Inyang, E.N.; McCartney, H.A.; Oyejola, B.; Ibrahim, L.; Pye, B.J.; Archer, S.A.; Butt, T.M. Effect of Formulation, Application and Rain on the Persistence of the Entomogenous Fungus Metarhizium anisopliae on Oilseed Rape. Mycol. Res. 2000, $104,653-661$. [CrossRef]

61. Klingen, I.; Hajek, A.; Meadow, R.; Renwick, J.A.A. Effect of Brassicaceous Plants on the Survival and Infectivity of Insect Pathogenic Fungi. BioControl 2002, 47, 411-425. [CrossRef]

62. Pilz, C.; Enkerli, J.; Wegensteiner, R.; Keller, S. Establishment and Persistence of the Entomopathogenic Fungus Metarhizium anisopliae in Maize Fields. J. Appl. Entomol. 2011, 135, 393-403. [CrossRef]

63. Zemek, R.; Konopická, J.; Ul Abdin, Z. Low Efficacy of Isaria fumosorosea against Box Tree Moth Cydalima perspectalis: Are Host Plant Phytochemicals Involved in Herbivore Defence against Fungal Pathogens? J. Fungi 2020, 6, 342. [CrossRef] [PubMed]

64. Inglis, G.D.; Goettel, M.S.; Butt, T.M.; Strasser, H. Use of hyphomycetous fungi for managing insect pests. In Fungi as Biocontrol Agents: Progress, Problems and Potential; Butt, T.M., Jackson, C., Magan, N., Eds.; CABI: Wallingford, UK, 2001; pp. 23-69, ISBN 978-0-85199-356-0.

65. Vandenberg, J.D.; Ramos, M.; Altre, J.A. Dose-Response and Age- and Temperature-Related Susceptibility of the Diamondback Moth (Lepidoptera: Plutellidae) to Two Isolates of Beauveria bassiana (Hyphomycetes: Moniliaceae). Environ. Entomol. 1998, 27, 1017-1021. [CrossRef]

66. Glare, T.R.; Milner, R.J. Ecology of entomopathogenic fungi. In Handbook of Applied Mycology; Arora, D.K., Ajello, L., Mukerji, K.G., Eds.; Marcel Dekker: New York, NY, USA, 1991; Volume 2, pp. 547-612. ISBN 978-0-8247-8435-5.

67. Ferron, P.; Fargues, J.; Riba, D. Fungi as microbial insecticides against pests. In Handbook of Applied Mycology; Arora, D.K., Ajello, L., Mukerji, K.G., Eds.; Marcel Dekker: New York, NY, USA, 1991; Volume 2, pp. 665-705. ISBN 978-0-8247-8435-5.

68. Tefera, T.; Vidal, S. Effect of Inoculation Method and Plant Growth Medium on Endophytic Colonization of Sorghum by the Entomopathogenic Fungus Beauveria bassiana. BioControl 2009, 54, 663-669. [CrossRef]

69. Raya-Diaz, S.; Sanchez-Rodriguez, A.R.; Segura-Fernandez, J.M.; del Campillo, M.C.; Quesada-Moraga, E. Entomopathogenic Fungi-Based Mechanisms for Improved Fe Nutrition in Sorghum Plants Grown on Calcareous Substrates. PLoS ONE 2017, 12, e0185903. [CrossRef]

70. Liu, H.; Bauer, L.S. Microbial Control of Emerald Ash Borer, Agrilus planipennis (Coleoptera: Buprestidae) with Beauveria bassiana Strain GHA: Greenhouse and Field Trials. Biol. Control 2008, 45, 124-132. [CrossRef] 
71. Mukawa, S.; Tooyama, H.; Ikegami, T. Influence of Humidity on the Infection of Western Flower Thrips, Frankliniella occidentalis (Thysanoptera: Thripidae), by Beauveria bassiana. Appl. Entomol. Zool. 2011, 46, 255-264. [CrossRef]

72. Clavet, C.; Hampton, E.; Requintina, M.; Alm, S.R. Laboratory Assessment of Beauveria bassiana (Hypocreales: Clavicipitaceae) Strain GHA for Control of Listronotus maculicollis (Coleoptera: Curculionidae) Adults. J. Econ. Entomol. 2013, 106, 2322-2326. [CrossRef] [PubMed]

73. Parker, B.L.; Skinner, M.; Gouli, S.; Gouli, V.; Kim, J.S. Virulence of BotaniGard ${ }^{\circledR}$ to Second Instar Brown Marmorated Stink Bug, Halyomorpha halys (Stål) (Heteroptera: Pentatomidae). Insects 2015, 6, 319-324. [CrossRef] [PubMed]

74. Ullah, M.S.; Lim, U.T. Laboratory Bioassay of Beauveria bassiana against Tetranychus urticae (Acari: Tetranychidae) on Leaf Discs and Potted Bean Plants. Exp. Appl. Acarol. 2015, 65, 307-318. [CrossRef]

75. Li, H.; Huang, D.; Wang, Z.; Yan, H.; Zheng, J. Screening Test of Highly Virulent Strains of Entomopathogenic Fungi Beauveria bassiana against Apriona germari Larvae. Sci. Silvae Sin. 2007, 43, 66-71.

76. Wang, Y.-C.; Chi, D.-F. Screening of High-Virulent Entomopathogenic Fungal Strains to Infect Xylotrechus rusticus Larvae. 3Biotech 2019, 9, 80. [CrossRef]

77. Guillebeau, L.P. Risk-Benefit Analysis of Pesticides: The U.S. Environmental Protection Agency Perspective. Am. Entomol. 1994, 40, 173-179. [CrossRef]

78. Wakil, W.; Kavallieratos, N.G.; Ghazanfar, M.U.; Usman, M.; Habib, A.; El-Shafie, H.A.F. Efficacy of Different Entomopathogenic Fungal Isolates against Four Key Stored-Grain Beetle Species. J. Stored Prod. Res. 2021, 93, 101845. [CrossRef]

79. Viaud, M.; Couteaudier, Y.; Levis, C.; Riba, G. Genome Organization in Beauveria bassiana: Electrophoretic Karyotype, Gene Mapping, and Telomeric Fingerprint. Fungal Genet. Biol. 1996, 20, 175-183. [CrossRef]

80. Maurer, P.; Couteaudier, Y.; Girard, P.A.; Bridge, P.D.; Riba, G. Genetic Diversity of Beauveria bassiana and Relatedness to Host Insect Range. Mycol. Res. 1997, 101, 159-164. [CrossRef]

81. Zhang, Z.; Lu, Y.; Xu, W.; Sui, L.; Du, Q.; Wang, Y.; Zhao, Y.; Li, Q. Influence of Genetic Diversity of Seventeen Beauveria bassiana Isolates from Different Hosts on Virulence by Comparative Genomics. BMC Genom. 2020, 21, 451. [CrossRef]

82. Feng, M.G.; Poprawski, T.J.; Khachatourians, G.G. Production, Formulation and Application of the Entomopathogenic Fungus Beauveria bassiana for Insect Control: Current Status. Biocontrol Sci. Technol. 1994, 4, 3-34. [CrossRef]

83. Jaronski, S.T. Mass Production of Entomopathogenic Fungi: State of the Art. In Mass Production of Beneficial Organisms; Elsevier: Amsterdam, The Netherlands, 2014; pp. 357-413. ISBN 978-0-12-391453-8. 